ELORE (ISSN 1456-3010), vol. $16-2 / 2009$.

Julkaisija: Suomen Kansantietouden Tutkijain Seura ry.

[http://www.elore.fi/arkisto/2_09/ajankoht_tiitola_2_09.pdf]

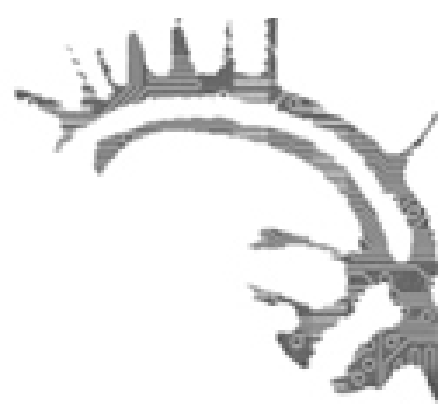

\title{
Ajankohtaista
}

\section{KALEVALAA, KERRONTAA JA KERTOMUKSIA}

Turun yliopiston folkloristiikan oppiaineen seminaarit keväällä 2009

\section{$\underline{\text { Kati Tiitola }}$}

Turun yliopiston folkloristiikan oppiaineessa järjestettiin huhtikuussa 2009 kolme seminaaria, jotka esittelen tässä raportissa. Ne käsittelivät monipuolisesti folkloristiikan ja kirjallisuustieteen näkemyksiä kertomusten tutkimuksessa, Kalevalaa kouluopetuksessa sekä folkloristiikan tutkimusta 2000-luvulla. Seminaarit toivat esille mielenkiintoisia näkökulmia folkloristiikan tutkimukseen sekä myös käytännönläheisempää lähestymistapaa folkloristiikkaan äidinkielenopettajille suunnatun seminaarin muodossa.

\section{SUULLISET JA KAUNOKIRJALLISET KERTOMUKSET - FOLKLORISTIIKAN JA KIRJALLISUUSTIETEEN NÄKÖKULMIA}

\subsubsection{9}

Turun yliopiston folkloristiikan oppiaine järjesti yhteistyössä yleisen kirjallisuustieteen ja kotimaisen kirjallisuuden oppiaineiden kanssa seminaarin, joka käsitteli kertomusten tutkimista folkloristiikan ja kirjallisuustieteen näkökulmista. Seminaarissa pohdittiin, miten näiden kahden tieteenalan näkökulmat aiheeseen ja metodit eroavat toisistaan ja mitä yhteistä niillä on. Luennoitsijoina seminaarissa toimi sekä kirjallisuustieteen että folkloristiikan alan tutkijoita ja opettajia Turun yliopistosta. Yleisöä paikalle oli saapunut nelisenkymmentä henkeä: paikalla oli kiitettävissä määrin myös opiskelijoita.

Seminaarin monipuoliset esitelmät tarjosivat laajan näkökulman folkloristiikan ja kirjallisuustieteen yhtäläisyyksiin ja eroavuuksiin kertomusten tutkimuksessa. Folkloristiikan päätoiminen tuntiopettaja Pasi Enges (Turun yliopisto) avasi seminaarin komeasti esittämällään balladilla "Aalonksi ja Emueli". Tämä oli hyvä johdanto aiheeseen, 


\section{KATI TIITOLA}

sillä balladin aihe esiintyy suomalaisessa kansanperinteessä, ja on levinnyt suulliseen perinteeseen kirjallisesta tekstistä. Folkloristiikan professori Pekka Hakamies (Turun yliopisto) tarjosi esitelmässään katsauksen folkloristiikan ja kirjallisuustieteen tutkimukseen. Hänen mukaansa sanataidetta voidaan pitää yhtymäkohtana kirjallisuuden ja folkloren välillä, sillä kummassakin tapauksessa hyvien kertojien merkitys on suuri. Myös yleisen kirjallisuustieteen professori Liisa Steinbyn (Turun yliopisto) esitelmä käsitteli kirjallisuustieteellisen tutkimuksen suuntauksia. Hän toi esille 1960-luvun lopussa syntyneen narratologisen tutkimuksen, joka pyrkii kertomuksen tutkimuksessa rakentamaan eksaktin terminologisen käsitteistön ja selvittämään yleisen rakenteen, jolla kertomuksia muodostetaan sekä historiallisen kontekstualisoivan kerronnantutkimuksen, jonka mukaan tietynlainen sisältö edellyttää tietynlaisia kerrontatapoja.

Lisää teoreettista näkökulmaa kirjallisuustieteelliseen kertomusten tutkimukseen tarjosivat yleisen kirjallisuustieteen assistentti Aino Mäki-Kalli (Turun yliopisto), jonka aihe käsitteli kertomuksen ajallisuuden tutkimusta, sekä kotimaisen kirjallisuuden professori Lea Rojola (Turun yliopisto), jonka aiheena oli luonnollisuuden käsite kerronnassa. Folkloristiikan tutkija Merja Leppälahden ja tohtorikoulutettava Tuomas Hovin lähestymistapa oli käytännönläheisempi. Leppälahti esitelmöi siitä, miten Kalevala on toiminut välittäjäteoksena suomalaisen kansanrunouden ja 2000-luvun kotimaisen kaunokirjallisuuden välillä. Hovin esitelmä taas käsitteli suullisten ja kirjallisten kertomusten käyttöä Dracula-turismissa.

Seminaari toi esille hedelmällisiä näkökulmia sekä folkloristiikan että kirjallisuustieteen oppien pohjalta ja loppukeskustelussa todettiinkin, että tieteenalat voivat oppia toisiltaan eroista, joita niiden välillä on. Folkloristiikan ja kirjallisuustieteen näkökulmat tulivat monipuolisesti esiin asiantuntevien esitelmien kautta, ja niissä oli sopivassa suhteessa teoriaa ja käytännön esimerkkejä. Toivottavasti mielenkiintoinen seminaari poikii myös jatkoa hyvin alkaneelle yhteistyölle näiden kahden tieteenalan välillä!

\section{SANAT SALASTA ILMI - KALEVALAN JA KANSANPERINTEEN OPETUS KOULUSSA 18.4.2009}

Kalevala-instituutti järjesti yhdessä Turun seudun äidinkielen opettajat ry:n kanssa Kalevalaa ja kansanperinteen opetusta kouluissa käsitelleen seminaarin, johon osallistui noin 50 äidinkielenopettajaa eri puolilta Suomea. Sen tarkoituksena oli kertoa, mitä Kalevalan ja eeppisen kansanrunouden tutkimuksessa on saatu selville ja tarjota tilaisuus kokemusten vaihtoon erilaisten työpajojen kautta. Seminaarissa oli luennoimassa Kalevalan ja eeppisen kansanrunouden tutkijoita.

Seminaarin luento-osuudessa avaajana toimi Pekka Hakamies, joka kertoi Kalevalan ja kalevalaisen kansanrunouden tutkimuksesta. Hän loi esitelmässään kattavan kuvauksen aiheeseen liittyvän tutkimuksen historiasta ja nykysuuntauksista. Folkloristiikan professori Lotte Tarkka (Helsingin yliopisto) luennoi kalevalamittaisesta kansanrunoudesta osana Vuokkiniemen kansanelämää 1800-luvulla. Hänen mukaansa Kalevalan ymmärtäminen edellyttää sekä eepoksen kirjallisen kontekstin ymmärtämistä että Elias Lönnrotin käytössä olleiden lähderunojen ja runonlaulajien kulttuurin ymmärtämistä. 
Omassa esitelmässään Tarkka tarjosi mielenkiintoisen näkökulman kalevalaisen kansanrunouden merkitykseen vienankarjalaisessa kansanelämässä 1800-luvulla, aikana, jolloin kansanrunous oli vielä osa kansanelämää. Hänen mukaansa kansanrunoutta voidaan pitää aktiivisesti luotuna suhteena menneisyyden, nykyhetken ja tulevaisuuden välillä. Tarkan mukaan luomalla yleiskuvaa runonlaulukulttuurista on mahdollista nähdä Kalevalan taakse ja ymmärtää vierasta kulttuuria. Tätä kautta kalevalaisen kansanrunouden tuntemus antaa myös aineksia oman kulttuurin ymmärtämiseen virallisen ja kansallisen viitekehyksen ymmärtämisen lisäksi.

Folkloristiikan väitöskirjaa valmisteleva filosofian maisteri Niina Hämäläinen (Turun yliopisto) esitteli omaa Kalevalan lyyrisiä runojaksoja ja Lönnrotin perhekäsitystä käsittelevää tutkimustaan. Hän etsii Kalevalan ja sen tekstualisaatioprosessin sekä Lönnrotin perhekäsityksiä koskevien kirjoitusten kautta vastausta siihen, oliko Kalevala myös kannanotto, jolla Lönnrot otti osaa julkiseen keskusteluun perheestä ja erityisesti naisen tehtävästä äitinä.

Folkloristiikan tutkija ja opettaja, filosofian lisensiaatti Jouni Hyvönen (Helsingin yliopisto) luennoi Lönnrotin toiminnan tieteellisistä ja aatteellisista lähtökohdista. Hänen tarkastelunsa kohteena olivat erityisesti Lönnrotin Juhana Kainulaiselta keräämät Kylvetyssanat: laaja riittikokonaisuus, jota tietäjä esitti sairasta parantaessaan. Hyvösen johtopäätös Lönnrotin toimitustyöstä ja strategisesta linjasta oli se, että hän pyrki tekstihierarkian yksinkertaistamiseen, tekstin luettelomaiseen kokoonpanoon, sekä lähderunojen tekstuaalisuuden korvaamiseen kollaasimaisella tekstikoosteella.

Merja Leppälahti kertoi luento-osuuden lopuksi nykyperinteestä. Hänen esimerkkinään toimivat nykytarinat, joille hänen mukaansa tyypillisiä piirteitä ovat rakenteellinen yksinkertaisuus, karmaiseva, pelottava tai koominen sisältö ja laaja levinneisyys. Leppälahti totesi nykyperinteen olevan arvokasta muun muassa siksi, että se auttaa ymmärtämään nykyisyyttä ja ihmistä itseään.

Luento-osuuden jälkeen seminaari jatkui työpajojen merkeissä, joita järjestettiin yhteensä viisi kappaletta. Niiden tarkoituksena oli jakaa ajatuksia siitä, miten Kalevalaa ja kansanperinnettä voidaan opettaa kouluissa. Työpajat käsittelivät Kalevala-aiheisia tekstitaitoharjoituksia, Kalevalan lähestymistä runon keinoin, pedagogista draamaa ja roolipeliä. Seminaarin yhteydessä Turun yliopiston Fennicumin aulaan oli koottu monipuolinen Kalevala-aiheinen näyttely, joka esitteli säkyläläisten ja turkulaisten yläasteikäisten koululaisten tekemiä oppilastöitä.

\section{FOLKLORISTIIKKAA 2000-LUVULLA 27.4.2009}

Turun yliopiston folkloristiikan oppiaine järjesti luentoseminaarin, joka esitteli nykyistä folkloristista tutkimusta kolmen korkeatasoisen luennon kautta. Luennoimaan Turkuun olivat saapuneet folkloristiikan emeritaprofessori Annikki Kaivola-Bregenhøj sekä Turun yliopiston folkloristiikan dosentit, Suomen Kotiseutuliiton toiminnanjohtaja Lassi Saressalo ja perinteentutkimuksen yliassistentti Sinikka Vakimo (Joensuun yliopisto). Luentoihin liittyi ennalta nimettyjen henkilöiden kommenttipuheenvuorot, jonka jälkeen esitettiin yleisökysymyksiä. Kaiken kaikkiaan seminaari tarjosi mielenkiin- 


\section{KATI TIITOLA}

toisia näkökulmia folkloristiikan tutkimukseen tieteenalan eri suuntauksista kokeneiden alan tutkijoiden esittäminä. Kommenttipuheenvuorot täydensivät luento-osuuksia hyvin, ja niiden pohjalta syntyi vilkasta keskustelua, johon myös yleisö otti osaa.

Annikki Kaivola-Bregenhøjn luennon teemana oli Kerrontaa, esityksiä ja esïntymisiä. Ydinkysymys hänen luennossaan oli, miten esiintyminen ja esittäminen eroavat toisistaan folkloristisessa tutkimuksessa ja milloin suullinen esitys muuttuu kerronnalliseksi. Kolme avainsanaa luennossa olivat esitys, esiintyminen ja performanssi. Kommenttipuheenvuoron Kaivola-Bregenhøjn luentoon piti filosofian tohtori, tutkija Tuija Hovi (Kirkon tutkimuskeskus). Hovi on tutkinut uskonnollissävytteistä kerrontaa, ja hänen mukaansa tärkeää ja ajankohtaista olisi tutkia narratiivisen tutkimuksen ja teknologian välistä suhdetta. Hän totesikin, että olisi syytä pohtia, onko esityksen ja esiintymisen tutkimus tarpeen myös virtuaalisessa aineistossa.

Lassi Saressalo luennoi aiheesta Etnisyyden monet kiemurat. Hänen luentonsa käsitteli etnisen ryhmän määrittelyä sekä etnisyyttä ja sen ilmenemistä folkloressa Ruijan alueella. Saressalon mukaan etniset konfliktit juontavat aina juurensa arvoasetelmaan, joka vallitsee etnisyyskysymyksissä. Tämä arvoasetelma jaottelee ihmiset "meihin" ja "muihin". Saressalo toi esille Karmela Liebkindin vähemmistö-enemmistö-strategiat ja puhui vähemmistöpolitiikan muodoista. Hän kertoi etnisyyden ilmenevän folkloressa muun muassa etnisinä stereotypioina, etnomyytteinä, etnotarinoina ja etnohuumorina. Saressalon luentoa kommentoi dosentti Marjut Anttonen, joka korosti etnisten ryhmien sisäistä diversiteettiä ja sitä, että etnisyys määritellään ryhmän sisällä aina tilanteesta ja kontekstista riippuen. Hän toi esille myös kansalaisuuden merkityksen etnisen identiteetin rakentumisessa.

Sinikka Vakimon aiheena oli Ikä-ja sukupuolinäkökulmia kulttuurin tutkimukseen. Hän korostikin luennossaan ikä- ja sukupuolinäkökulman huomioonottamisen tärkeyttä kulttuurien tutkimuksessa. Vakimo tarkasteli myös folkloristiikan historiaa ikäkriittisestä näkökulmasta. Hän toi esille esimerkkinä ikädiskursseista neljä tapaa esittää vanha nainen Suomen taiteen kultakauden teoksissa. Kommenttipuheenvuoron Vakimon luennosta piti filosofian tohtori Lena Marander-Eklund (Åbo Akademi). Hän pohti puheenvuorossaan, mistä keskustelun puute ikäkysymyksissä johtuu ja mainitsi "sokeat pisteet", jotka tutkimusta tehdessä tulisi ottaa huomioon. Marander-Eklund on itse tutkinut muun muassa 1950-luvun kotiäitejä ja todennut heidän ryhmänsä muodostavan tällaisen "sokean pisteen", josta aineistot vaikenevat.

Humanististen tieteiden kandidaatti Kati Tiitola toimi keväällä 2009 folkloristiikan oppiaineen harjoittelijana Turun yliopistossa. 